\title{
OPPORTUNITIES DUE THE SECONDARY SCHOOL TEACHER OF PHYSICS.*
}

\section{(a). For Study and Improvement.}

(b). For the Preparation of Lectures and Laboratory Work.

\author{
By Dr. William C. Collar, \\ Roxbury Latin School, Roxbury, Mass.
}

As I read the two topics, the thought occurred to me that your president has just expressed, that the two subjects did not seem to have a very close relation, they seemed, in fact, to be independent of each other; the first points to the advancement of the teacher, and the second seems to concern itself with the good of the pupils. But a second thought shows that there is an underlying idea which unites and binds these two topics together, that is, the topics mean opportunities for effective teaching of physics, or perhaps the most favorable opportunities for the most effective teaching of physics; and that formula may perhaps be reduced to simply this: Ideal conditions of teaching physics. And so I want to say a few words about the ideal conditions of teaching generally, and especially of teaching physics.

I am afraid you may wince a little at the word "ideal;" you may anticipate something that is too much in the air, something that has not its feet planted on the earth. I imagine you are thinking to yourselves, "Why talk about ideals? Our difficulties are of a practical sort, and what we want is a practical solution." In reply to that, I have to say that I think ideals are the most practical things of all-that ideals at least have their practical side. They ought to govern, guide, and inspire practice. I believe you all have ideals whether you realize them in consciousness or not; for without ideals, you would surely be like a man launching his bark upon the sea without a chart, rudder, or compass, and without knowing whither his royage is tending. And if it were not for this practical side of ideals, I still say that we ought to cherish them with all fondness, as an antidote to the actual conditions in which we find ourselves. Our lives generally, our lives as teachers, and our lives specially as physics teachers, I imagine are often quite un-ideal, often depressing, if not discouraging, and we need to cherish ideals to forget, in some measure, the actual conditions under which we work. The

\footnotetext{
*Address at the March meeting of the Eastern Association of Physics Teachers held at Roxbury, Mass.
} 
cherishing of ideals tends to give courage and hope. I know it is so with me.

Now, the first of the ideal conditions that I wish to speak of is the condition of mastery of your subject. Do I know myself what I really mean by mastery of a subject? I can say one or two things that I do not mean, and that will bring us a little nearer. By mastery of a subject I do not mean knowing every possible thing about it, because I suppose however small might be the subject, to know all that is possible to be known would take more than a lifetime. Certainly the ramifications of every subject are infinite and countless in number, and I realize what our state as teachers is, and what is possible and what is not. Nor do I mean by mastery of a subject, that one should have the knowledge of an expert, who has devoted his life, perhaps, to some small part of human learning and teaching.

A teacher should know his subject accurately as far as he has to teach it and he must know more than he has to teach, or he cannot teach well, must know far more than he conld expect to impart to any scholar. He must have a knowledge of his subject in perspective. He must be able to see the subject in its right relations.

What does mastery of a subject do for you? As a teacher, it must be of use in the presence of your class; it gives you confidence and that your pupils are sure to feel; it gives you power over yourself; it puts into your hands all the faculties that you possess. My own experience has been, that when I know my subject especially well, it induces a kind of elevation of spirit, and the effect of that is manifest in my class. I have not often to reprove my boys or to complain that they sit before me like graven images, irresponsive to my teachings. I do sometimes in my eagerness to know whether they really understand and appreciate, request them to smile or to wrinkle their brows, to make some sign that the thing is touching them. In general, that is not necessary; if I do feel in myself enthusiasm, it is infectious; the class feel it, and they show it in their responsive smiles.

Now, a second of the ideal conditions for the teacher of physics seems to be adequate time for his work and for study. I think that the feeling of the public, of school committees, and of many head masters is, that the more teachers teach, the better they earn their wage. This seems to be a grave mistake. I have acted on a very different principle, and have sought always to reduce the time my teachers had to teach, and 
to limit as far as I could, the number of papers that they must correct.

I said last spring in New Haven, that in my judgment it ought to be agreed and understood that teachers are hired about as much to study as they are to teach, and I had the temerity to say I thought I was propounding a new doctrine, a strange gospel. But reflecting upon this I said to myself, "This is recognized and is actually practiced to some extent, now, in some communities, where they give the teacher occasionally periodical years to devote to study with half salary."

I remember several years ago, a professor in Harvard, who is eminent as a teacher and eminent as an editor, told me that he met classes ten times a week, and that it was altogether too much. I knew a good deal of his work, it was not unlike mine in classes in Homer. It was partly lecturing, but he said it was altogether too much, and he went to the corporation and said, "Gentlemen, I cannot do ten hours a week, it must be reduced to four, and if you find it needful to reduce my salary you may do so, but I cannot teach more than four hours." And I presume he was relieved of the ten classes a week, for he has been teaching four times a week for years.

Another ideal condition is, not too many pupils in a class or in a division. President Eliot, several years ago, is reported to have said publicly in Chicago, that he thought there should be not more than five pupils to a teacher. The thought seemed rather surprising, but when I reflected on the president's experience and observation, I was not so much surprised; as at that very time, there were only ten or twelve students to an instructor on the average in Harvard College proper, and in the Medical School there are three students to a teacher now. We cannot expect so few as that. I think it is, perhaps, desirable to have enough so as to have more or less of a spirit of rivalry in the class. Many years ago, Dr. Hale, twenty-three years a trustee of this school, came into my room and listened to a recitation, and he said, "It is all very pleasant and delightful, but you have too many pupils, you should not have more than fifteen." I had twenty-five pupils. I think Dr. Hale was pretty nearly right, and I should judge for a teacher of physics that that number is a fair average. And then a smaller number in a class or a division means fewer books to read, examine and mark. We must have tests and exxaminations, but to a large extent they are an evil, and not a thing desirable in themselves; and for a 
teacher, after his day's work, or a part of his day's work, to examine many books or many papers, is certainly very wearying. Such work ought to be kept within reasonable limits, and that can be done if the numbers are not too large.

Another of the ideal conditions I should name is freedom. I think that fetters are not good for any human being, and so not for a teacher of physics. A man ought to be allowed, it seems to me, to find his own methods, to be free to produce his own results after his own notions. I presume that it may be true that if you are assistants, not heads of schools, you have liberty in the teaching of physics, because I inagine that head masters are too busy to look into the matter of methods, or if they are as ignorant as I am of the subject that they generally have the good. sense to keep away and let the physics teacher do what he likes. Freedom you must have, and the most desirable freedom of all, is, perhaps, the exemption from bringing in all of a class or a division up to a certain point of knowledge on a given day. That is to my mind ridiculous. You have to strugggle to do the impossible in a great many cases, and I think that the worst form of slavery. Now if any one should come into my Latin or Greek recitations, it might happen that he would find me interested in the argument of the oration of Cicero that we were on, or in the literary style, or what constituted the effectiveness of the appeal to the jury, or I might be wielding the syntactical rake and examining subjunctives and ablatives, or I might be giving all my time to translation. "Why did you choose that word, what is the difference in force between this and that?" Meantime I should be seeming to exclude everything else, and so might a visitor say. and with apparent justice might make a very severe criticism. I have in that respect absolute freedom. I enjoy most of the ideal conditions that I am speaking of to you, and I am the only teacher in this school who does enjoy them. I teach fourteen out of thirty periods a week.

I will say in conclusion, that science has had to take a back seat in schools. I was in England sixteen years ago, and was interested in the subject of science teaching in the schools. I visited some of the great classical schools, and was surprised to find that science in some form was getting a place in them, but it was always in spite of the head master. I did not learn anywhere of a head master who showed any sympathy. They spoke of science with contempt, but I am persuaded that it is' going to come to the front, and that very soon, and I say for your en- 
couragement I believe that it is altogether an injustice that in any schools, especially in any classical schools, science should be depreciated. I want to read you a few words from an author whom, in general, I greatly admire:

"I hate and fear 'science' because of my conviction that for long to come if not forever, it will be the remorseless enemy of mankind. I see it destroying all simplicity and gentleness of life, all the beauty of the world; I see it restoring barbarism under a mask of civilization. I see it darkening men's minds and hardening their hearts."

I read that to show you how absolutely antipodal that is to my own feeling towards science. "It is and will be the remorseless enemy of mankind." Had the man not thought at all of the enormous alleviation of human suffering that we owe to science? I wonder if he forgot what we owe to science in the matter of sanitation and hygiene and the knowledge of how to live like human beings on this earth. "I see it darkening their minds and hardening their hearts." I think of a passage in Homer. In Homer the spirit of mischief, Ate, is personified. Ate strides through the wotld doing harm, and prays, Litae, follow after, correcting the evil that Ate has brought. As I think over the history of our race, I see how the dark and evil spirit of ignorance and superstition, like Ate, has borne heavily upon man through the ages, causing infinite wre; and then how in these days science like the Litae in Homer has followed after and is shedding, like a blessed angel, light and hope and comfort and peace upon mankind.

A Iaper by Bruce V. Hill in the April Physical Review contains the following interestiog statements:

"An alloy of 34 per cent nickel and 66 per cent steel forms the nonexpansive alloy of Guillaume. Its coefficient of linear expansion is .000001 . Block pendulums made of this material vary so little in length that a clock thus provided will run more accurately than other clocks with the ordinary compensating devices.

"The steels with 40 to 50 per cent of nickel luave so nearly the sime coefficient of expansion as glass that they may be employed when it is desired to seal a metal into glass. This material called 'Platinite' had already begun to replace platinum in the manufacture of incandescent lamps in France several years ago." 